\title{
A DEVELOPED SOLAR COMBINATION UNIT FOR COOKING AND WATER DESALINATION
}

\author{
Mona M. A. Hassan ${ }^{1}$ and K. I. Wasfy ${ }^{1}$
}

\section{ABSTRACT}

A solar combination unit was developed be suitable for cooking and water desalination. Ordinary solar box cooker was developed to be accommodate for desalination and cooking. Different configurations were carried out under study as: Cooker without mirror reflector $\left(C_{1}\right)$, Cooker with mirror reflector $\left(C_{2}\right)$, Cooker integrated with flat-plate solar collector $\left(C_{3}\right)$ and Cooker integrated with mirror reflector and flat-plate solar collector $\left(C_{4}\right)$. Fourth merit figure and overall thermal cooking efficiency were applied under water load densities of 1.0, 1.5, 2.0 and 2.5 $L$ to select the highest system performance. Preliminary experiments clarified that using $C_{4}$ system and $1.5 \mathrm{~L}$ of water gave the highest efficiency compared to other treatments.

Thermal analysis was done based on internal and external heat transfer to predict the used $C_{4}$ behavior. The performance evaluation was conducted as a function of change in different brine depths of 1, 2 and 3 $\mathrm{cm}$ under conditions of groundwater desalination, cooking rice $\left(T_{1}\right)$, potato $\left(T_{2}\right)$, cake $\left(T_{3}\right)$ and egg + potato + rice $\left(T_{4}\right)$ and desalinationcooking combined systems. This is in terms of system productivity, internal and instantaneous thermal efficiencies and cooking time. Experimental results revealed that the use of desalination-cooking combined system gave the highest distillate water productivity $(9.38$ $\mathrm{L} / \mathrm{m}^{2}$.day) as well as internal and instantaneous efficiencies $(60.17 \%$ and $41.43 \%$ ), added to that decreased the cooking time; $T_{1}$ (39 $\left.\mathrm{min}\right), T_{2}$ (43 $\mathrm{min}), T_{3}(49 \mathrm{~min})$ and $T_{4}(100 \mathrm{~min})$ under condition of $1 \mathrm{~cm}$ brine depth.

Keywords: Solar box cooker, Flat-plate solar collector, Water desalination, Performance evaluation, Distillate water productivity.

\section{${ }^{1}$ Assistant prof. of Agric. Eng., Fac. of Agric., Zagazig Univ.}




\section{INTRODUCTION}

hortage of energy and fresh water are two main challenges for the world in the future and a crucial role in the economic development of country. The major portion of energy consumption in developing countries is for cooking, consequently solar energy is used for cooking purpose. The classifications of the solar stoves were based on the type of the collector and the place of the cooking. In the case of a direct system with a flat plate solar collector, cooking pans were placed directly in the collector but in the indirect system the energy was transported from the collector to the cooking place by a heat transfer medium (Hafner and Schwarzer, 2000). There has been a considerable recent interest in the design, development and testing of various types of solar cookers. The box type solar cooker is cheaper, easy to handle and effectively working. The productivity of humidification-dehumidification (HDH) desalination system depends on the saline water inlet temperature, air flow rate and cooling water flow rate (Al-Enezi et al., 2006). Yuan et al. (2011) conducted experimental investigation of a $1000 \mathrm{~L} /$ day solar HDH system. That system was composed of a $100 \mathrm{~m}^{2}$ solar air heater field, a $12 \mathrm{~m}^{2}$ solar water collector, a humidifier-dehumidifier unit, a pretreatment and post-treatment system. The results showed that water production of the system could reach $1200 \mathrm{~L} /$ day when average intensity of solar radiation was $550 \mathrm{~W} / \mathrm{m}^{2}$. Mona (2012) enhanced the incident solar radiation of solar cooker with one reflector and developed it to be used as a solar dryer to make this system as multi purposes. Obtained data showed that the values of thermal efficiency were $45.3,67.6$ and $74.47 \%$ for $1.0,1.5$ and $2.0 \mathrm{~kg}$ of water, respectively. The cooking times were 70,80 and 95 minutes for rice, potatoes slices and cake, in that order. Drying onion reached to moisture content of $25 \%$ (d.b.) in $9 \mathrm{~h}$, while drying apricot arrived to $10.31 \%$ (d.b.) in $14 \mathrm{~h}$. Simple and Page's models gave satisfactory description during the drying process. Kabeel et al. (2013) found that the $\mathrm{HDH}$ will be a suitable choice for distillate water production. $\mathrm{HDH}$ is a low temperature process where total required thermal energy can be obtained from solar energy. It was observed that an increase in evaporator and condenser surface areas significantly improves system productivity. Moumouh $\boldsymbol{e t}$ al. (2016) proposed a theoretical and experimental study of desalination system based on air humidification 
dehumidification. The results obtained from the theoretical model are in very good agreement with those obtained experimentally. Bhalme and Pachghare (2017) investigated the effect of using an induced air, ambient temperature and different mass flow rates of air on the performance augmentation of humidification-dehumidification (HDH) system. This system is designed to produce $5-6 \mathrm{~L}$ of water per day. The operational parameters included different air flow rate, feed water flow rate and temperature. Results clarified that the system performance was increased by increasing flow rate of air. The highest production rate of distillate water is $480 \mathrm{~g} / \mathrm{h}$. Water production tests were performed out on several typical days when the average intensity of solar radiation got to 297.5 $\mathrm{W} / \mathrm{m}^{2}$. Srithar and Rajaseenivasan (2017) fabricated a solar bubble column humidifier coupled to a single slope solar still. Preliminary experiments were carried out to study the ability of the bubble column humidifier and then, the humidifier connected with a dehumidifier to analyze the overall system performance. Integration of solar air heater showed considerable enhancement of specific humidity in the humidifier outlet. The humidifier inserted with the solar air heater containing concave tabulators provided the maximum gain $0.187 \mathrm{~kg}_{\text {water }} / \mathrm{kg}_{\text {air }}$ specific humidity. Whereas the humidifier integrated with the solar air heater without tabulator gave the maximum specific humidity gain of about $0.11 \mathrm{~kg}_{\text {water }} / \mathrm{kg}_{\text {air }}$. The peak distillate of collected daily water was $20.61 \mathrm{~kg} / \mathrm{m}^{2}$.

Above literatures showed that numbers of works were carried out to increase the ability of desalination humidifier or solar cooker, but the authors have not found a combination of solar cooker with solar desalination. So, this is a trial for investigation with the aim of producing high production rate of distillate water with least cooking time at the same time.

Thereby, the major aim of the present research is to develop a solar combination unit by integrating the solar box type cooker with solar air collector to be used in cooking and water desalination as multi-purposes unit at the same time.

\section{MATERIALS AND METHODS}

The present research was conducted at the Faculty of Agriculture, Zagazig University, Zagazig city $\left(30^{\circ} 20^{\prime} \mathrm{N}\right.$ latitude and $31^{\circ} 20^{\prime} \mathrm{E}$ 
longitude), Egypt during the period from 1/4/2018 to 15/5/2018 in order to enhance the box-cooker performance to be used as multi-purposes in cooking and water desalination. Climatic conditions of the experimental area were shown in Table 1.

\section{Table 1. Climatic conditions of the experimental location}

\begin{tabular}{lcc}
\hline \multicolumn{1}{c}{ Conditions } & Experimental periods (2018) \\
\hline Max. Temperature $\left({ }^{\circ} \mathbf{C}\right)$ & 29.50 & 31.0 \\
Min. Temperature $\left({ }^{\circ} \mathbf{C}\right)$ & 16.00 & 19.0 \\
Avg. Wind speed $(\mathbf{k m} / \mathbf{h})$ & 2.88 & 2.2 \\
Solar intensity $\quad\left(\mathbf{W} / \mathbf{m}^{2}\right)$ & 333.50 & 550.0 \\
\hline
\end{tabular}

\section{Materials}

\subsection{Ordinary solar box type cooker}

Box-type solar cooker before development, as shown in Fig. 1 is popular and widely used due to its simplicity and low cost. It was previously constructed and evaluated by Mona (2012).

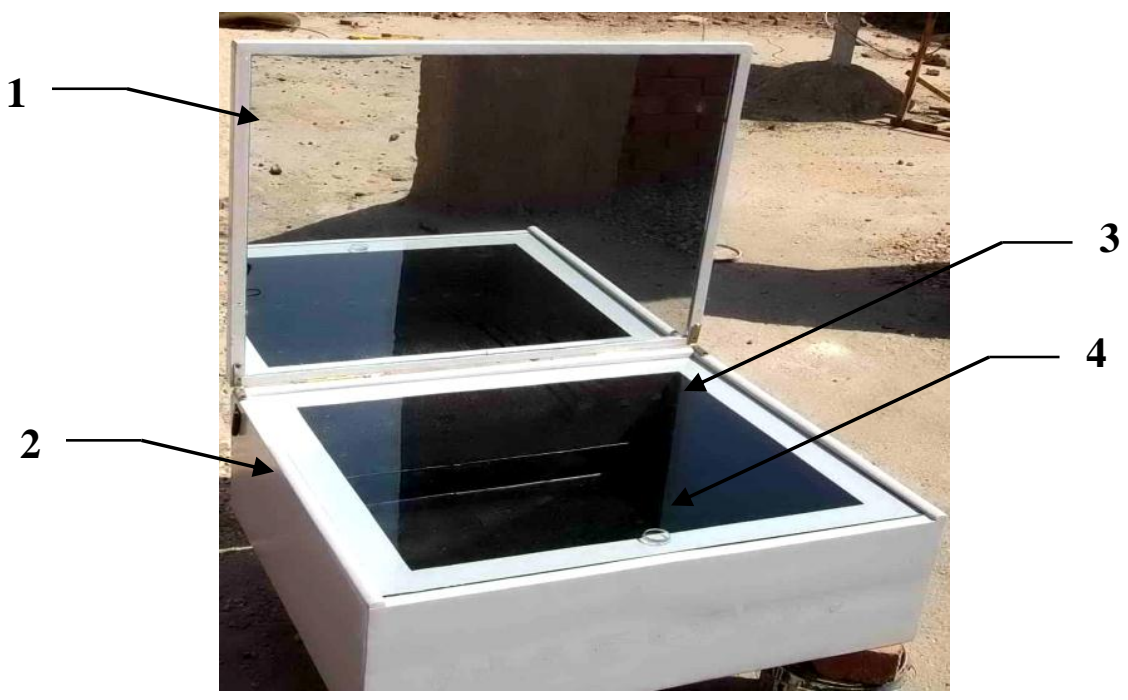

1. Mirror reflector 2. Cooker frame 3. Glass cover 4. Absorber plate Fig. 1. Ordinary solar box type cooker

It was made from wood with $15 \mathrm{~mm}$ thickness and $700 \times 600 \times 240 \mathrm{~mm}$ dimensions. Bottom and side walls of the cooker were covered by glass wool $40 \mathrm{~mm}$ to minimize the heat losses. Absorber galvanized sheet steel 
plate of $5 \mathrm{~mm}$ thickness was put on the base inside the cooker and painted with black to improve its absorptivity and thermal conductivity. The cooker was covered by plane tempered glass $5 \mathrm{~mm}$ thickness to provide high optical transmittance. The cooking pot was made from black painted aluminum in cylindrical shape with volume of $3.46 \mathrm{~L}$. The cooker was connected with mirror reflector which fixed on the frame $(700 \times 600$ $\mathrm{mm})$.

\subsection{Development of solar combination unit for desalination and cooking}

The developed unit consists mainly of raw water tank, connecting pipes, solar cooker and flat-plate solar collector as shown in Figs. 2 and 3.

1.2.1. The raw water tank: It was put at a uniform position from the system in order to permit the flow of water from its outlet hole through a hand valve with different flow rates to the base of solar cooker.

1.2.2. The solar cooker: It consists of the same parts of ordinary solar cooker as previously described but with double slope glass cover on the top surface of cooker instead of plane glass cover to be suitable for cooking and desalination. The double slope glass cover was oriented east west with $5 \mathrm{~mm}$ thickness, $20 \mathrm{~cm}$ height and an inclination angle of $20^{\circ}$.

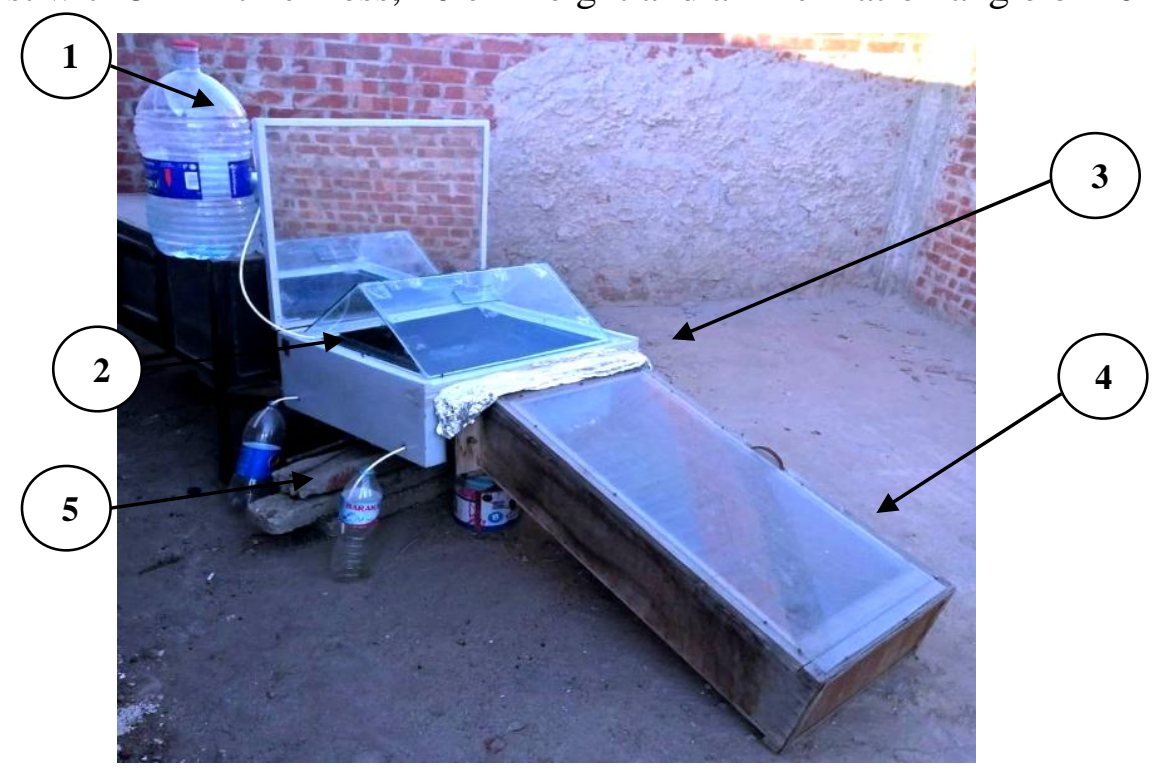

1. Saline water tank

2. Feeding inlet

3. Box type cooker

4. Flat-plate solar collector

5. Distillate water outlet

Fig. 2. Photo of the developed solar combination unit for cooking and water desalination 
Black sheet steel plate was put at a height of $15 \mathrm{~cm}$ from the base to decrease the enclosed area inside the cooker and thereby, increase the inside temperature.

The glass cover water cooling was controlled manually by flash tactics every $15 \mathrm{~min}$ to decrease the cover surface temperature and thereby, increase the condensation rate and the distillate outlet.

The produced distillate water in desalination process was collected from the bottom to the calibrated cylinder. For enhancing the evaporation rate, flat-plate solar collector was connected to the base of solar cooker.

1.2.3. Flat-plate solar collector: It was constructed from a wooden frame as low cost, local material. It had a rectangular section shape $(1000 \times 500$ x $200 \mathrm{~mm}$ ). Absorber plate was made from corrugated galvanized iron sheet $5 \mathrm{~mm}$ thickness, painted with black in order to increase the absorption of solar energy. The top surface of the solar collector was glazing cover with $5 \mathrm{~mm}$ thickness. The air collector was faced south and titled at $30^{\circ}$ with the horizontal level. Perforated stainless steel sheet as a rectangular shape $(200 \times 200 \mathrm{~mm})$ was installed on the front side of air inlet.

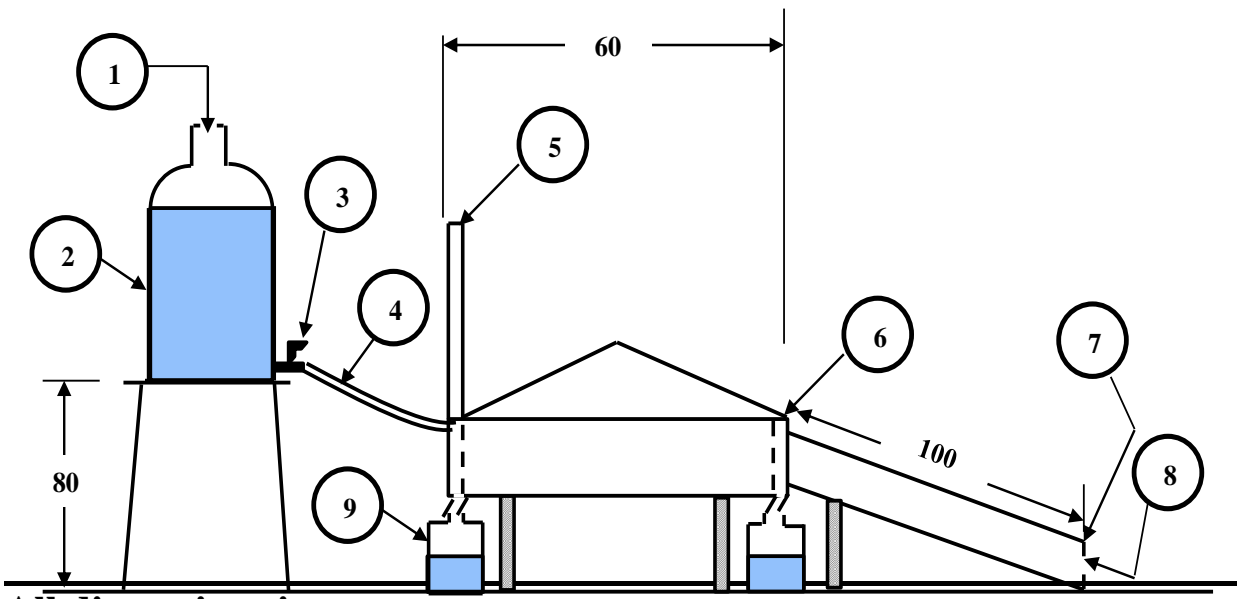

All dimensions in cm.

1- Saline water input

2- Saline water tank 3- Hand valve

4- Connecting pipe

5- Mirror reflector

6- Double slope solar cooker

7- Flat-plate solar collector 8- Air inlet gate 9-Distillate water outlet

Fig. 3. Elevation of the developed solar combination unit for cooking and desalination unit 


\subsection{Saline water}

Ground water of $4.3 \mathrm{dS} / \mathrm{m}$ was used in the present work to study the performance of the developed unit in desalination process.

\section{Methods}

Experiments were carried out from 10 a.m. to 6 p.m. in order to select the proper conditions for producing high distillate water productivity with least cooking time. Solar radiation, temperature and humidity were recorded during the experiments.

\subsection{Experimental procedure}

Five experiments were carried out as follow:

\section{- First experiment}

Different treatments without loads were done in the developed solar combination unit for promoting the efficiency as: Solar unit without mirror reflector $\left(\mathrm{C}_{1}\right)$, solar unit with mirror reflector $\left(\mathrm{C}_{2}\right)$, solar unit integrated with flat-plate solar collector $\left(\mathrm{C}_{3}\right)$ and solar unit integrated with mirror reflector and flat-plate solar collector $\left(\mathrm{C}_{4}\right)$

\section{- Second experiment}

The second experiment was done under different water loads of 1.0, 1.5, 2.0 and $2.5 \mathrm{~L}$.

\section{- Third experiment}

Four different cooking products as: $\left(\mathrm{T}_{1}\right)$ rice, $\left(\mathrm{T}_{2}\right)$ potato, $\left(\mathrm{T}_{3}\right)$ cake, $\left(\mathrm{T}_{4}\right)$ egg+ potato+ rice.

\section{- Fourth experiment}

Three brine depths of 1,2 and $3 \mathrm{~cm}$ for desalination.

\section{- Fifth experiment}

Combination of previously cooking products with suggested optimum brine depth.

\subsection{Measurements and Determinations}

The following measurements were taken to evaluate the performance of the developed unit:

\subsubsection{Solar intensity}

It was measured by using pyranometer sensor model KIPP \& ZONEN $\mathrm{CM}_{6} \mathrm{~B}$ with sensitivity of $12.11 \times 10^{-6} \mathrm{~V} / \mathrm{Wm}^{-2}$. The solar intensity $\left(\mathrm{W} / \mathrm{m}^{2}\right)$ of the experimental period was measured per hour intervals. 


\subsubsection{Temperature}

Temperatures were measured with hour intervals using thermocouples $\mathrm{K}$ type (YF-160A) made in Taiwan and connected to a multi-digital display with an accuracy of $0.05^{\circ} \mathrm{C}$.

\subsubsection{Thermal Figures of Merit}

These fourth figures were applied under first and second experiments to select the highest performance of different tested systems as:

\subsubsection{Standard stagnation temperature $(S S T)$}

It is the highest air temperature $\left({ }^{\circ} \mathrm{C} \cdot \mathrm{m}^{2} / \mathrm{W}\right)$ that reached inside the cooking pot under normal conditions. SST was calculated at stable temperature at about $2-3 \%$ or passed 2 hours by using the following equation:

$S S T=\left(T_{P S}-T_{a}\right) / I_{m e a s u r e d}$

Where: $T_{p s}$ is plate stagnation temperature $\left({ }^{\circ} \mathrm{C}\right) ; T_{a}$ is an ambient air temperature $\left({ }^{\circ} \mathrm{C}\right) ; I_{\text {measured }}$ is the horizontal insolation $\left(\mathrm{W} / \mathrm{m}^{2}\right)$

\subsubsection{Standard cooking power $\left(\boldsymbol{P}_{n}\right)$}

Standard cooking power is the delivered power (W) under normalized insolation. The cooking pot was filled with different masses of distilled water. Data were recorded in an hour intervals when the water reached its boiling temperature. The cooking power $(\mathrm{P})$ was determined according to ASAE Standards S580 (2003) as follow:

$P=M \times C\left(T_{2}-T_{1}\right) / 3600$

Where: $M$ is the mass of water in cooking pot $(\mathrm{kg}) ; C$ is specific heat of water $\left(\mathrm{J} / \mathrm{kg} .{ }^{\circ} \mathrm{C}\right) ; T_{2}$ is the water temperature at end of interval $\left({ }^{\circ} \mathrm{C}\right)$ and $T_{1}$ is water temperature at beginning of interval $\left({ }^{\circ} \mathrm{C}\right)$.

The cooking power $\left(P_{n}, \mathrm{~W}\right)$ is then normalized to a standard insolation $\left(850 \mathrm{~W} / \mathrm{m}^{2}\right)$ and determined by using this formula:

$P_{n}=P\left(850 / I_{\text {measured }}\right)$

These equations were done by plotting $P_{n}$ against $\Delta T$ and performing a linear regression, where $\Delta \mathrm{T}$ refers to $\mathrm{T}_{\text {water }}-\mathrm{T}_{\text {ambient. }}$. This test should be done after 4 hours from the starting or when temperature reached to $95^{\circ} \mathrm{C}$.

\subsubsection{Standard sensible heating time $\left(T_{0}\right)$}

This figure describes the duration time that take to heat a known quantity of water to $50^{\circ} \mathrm{C}$ above ambient temperature per hour under a standard insolation of $850 \mathrm{~W} / \mathrm{m}^{2}$.

$T_{0}=\left(I \Delta T_{0} t\right) /\left(I_{0} \Delta T\right)$ 
Where: I is the horizontal irradiance averaged over entire interval $\left(\mathrm{W} / \mathrm{m}^{2}\right)$; $\Delta \mathrm{T}_{0}$ is $50^{\circ} \mathrm{C}$; $\mathrm{t}$ is Measured interval (hours); $\mathrm{I}_{0}$ is a standard insolation $\left(850 \mathrm{~W} / \mathrm{m}^{2}\right)$ and $\Delta \mathrm{T}$ is temperature difference over measured interval $\left({ }^{\circ} \mathrm{C}\right)$.

\subsubsection{Unattended cooking time $\left(t_{c, s}\right)$}

Unattended cooking time (hour) describes that how long cooker can retain the temperatures of cooking unattended. It is conducted until the temperature of the water decreases by $20^{\circ} \mathrm{C}$ from its starting temperature as:

$$
T_{c, s}=t_{c}\left(I_{0} / I\right)
$$

Where: $t_{c, s}$ is standardized cooling time (hours) and $t_{c}$ is the cooling time measured (hours)

\subsubsection{Cooking thermal efficiency $\left(\eta_{u}\right)$}

Thermal efficiency (\%) was calculated as El-Sebaii and Ibrahim (2005):

$\boldsymbol{\eta}_{u}=\left[\left(\boldsymbol{m}_{w} \boldsymbol{C}_{w} \Delta \boldsymbol{T}\right) /\left(\boldsymbol{I}_{\text {avg }} \boldsymbol{A}_{\boldsymbol{c}} \Delta t\right)\right] \times \mathbf{1 0 0}$

Where: $m_{w}$ is the mass $(\mathrm{kg}) ; C_{w}$ is specific heat of water $\left(\mathrm{J} / \mathrm{kg}^{\circ} \mathrm{C}\right) ; \Delta T$ is the temperature difference between the maximum temperature of water and the mean ambient air temperature during the interval $\Delta t\left({ }^{\circ} \mathrm{C}\right) ; I_{\text {avg }}$ is the solar intensity during the time interval $\left(\mathrm{W} / \mathrm{m}^{2}\right)$ and $A_{c}$ is the cooker area $\left(\mathrm{m}^{2}\right)$.

\subsubsection{Distillate water productivity}

System productivity was recorded in an hour intervals by calibrated cylinder. It was defined as a total distillate volume that produced in a day per unit area.

\subsubsection{Distillation thermal efficiencies}

Internal heat transfer occurs from water surface to inner surface of the glass cover, which mainly consists of evaporation, convection and radiation according to Sampathkumar et al. (2010). The convective and evaporative heat transfers takes place simultaneously and are independent of radiative heat transfer.

The rate of radiative heat transfer between water to glass is presented as,

$q_{r, w-g}=h_{r, w-g}\left(T_{w}-T_{g i}\right)$

The radiative heat transfer coefficient $\left(h_{r, w-g}\right)$ between water to glass is given as,

$h_{r, w-g}=\varepsilon_{\text {eff }} \sigma\left[\left\{\left(T_{w}+273\right)^{4}+\left(T_{g i}+273\right)^{4}\right\} /\left\{T_{w}+T_{g i}+546\right\}\right]$

The effective emittance $\left(\varepsilon_{\text {eff }}\right)$ between water $\left(\varepsilon_{\mathrm{w}}\right)$ to glass $\left(\varepsilon_{\mathrm{g}}\right)$ cover is presented as, 
$\varepsilon_{\text {eff }}=\left[1 /\left\{\left(1 / \varepsilon_{g}\right)+\left(1 / \varepsilon_{w}\right)-1\right\}\right]$

Where: $\sigma$ is Stefan-Boltzman's constant $\left(\sigma=5.67 \times 10^{-8} \mathrm{~W} / \mathrm{m}^{2} \cdot \mathrm{K}^{4}\right), \mathrm{T}_{\mathrm{w}}$ is water temperature, ${ }^{\circ} \mathrm{C}$ and $\mathrm{T}_{\mathrm{gi}}$ is temperature of inner glass, ${ }^{\circ} \mathrm{C}$.

The rate of convective heat transfer between water to glass is given as:

$q_{c, w-g}=h_{c, w-g}\left(T_{w}-T_{g i}\right)$

The convective heat transfer coefficient $\left(\mathrm{h}_{\mathrm{c}, \mathrm{w}-\mathrm{g}}\right)$ depends on the temperature difference between evaporating and condensing surface, physical properties of fluid, flow characteristic and condensing cover geometry. It is expressed as,

$h_{c, w-g}=0.884\left[\Delta T^{\prime}\right]^{1 / 3}$

$\Delta T^{\prime}=\left(T_{w}-T_{g i}\right)+\left[\left\{\left(P_{w}-P_{g i}\right)\left(T_{w}+273\right)\right\} /\left\{268.9 \times 10^{-3}-P_{w}\right\}\right]$

$\boldsymbol{P}_{w}=e^{\left(25.317-\frac{5144}{T_{w}}\right)}, \quad \boldsymbol{P}_{g i}=e^{\left(25.317-\frac{5144}{T_{g i}}\right)}$

The general equation for the rate of evaporative heat transfer between water to glass is given as,

$q_{e, w-g}=h_{e, w-g}\left(T_{w}-T_{g i}\right)$

The evaporative heat transfer coefficient $\left(\mathrm{h}_{\mathrm{e}, \mathrm{w}-\mathrm{g})}\right)$ is expressed as, $h_{e, w-g}=16.273 \times 10^{-3} \times h_{c, w-g}\left[\left(P_{w}-P_{g i}\right) /\left(T_{w}-T_{g i}\right)\right]$

Based on above mentioned, instantaneous and internal efficiencies were determined according to Tiwari $\boldsymbol{e t}$ al. (2003) as:

\section{Instantaneous efficiency $\left(\boldsymbol{\eta}_{i}\right)$}

It is defined as the ratio of the heat transferred that used for evaporation $\left(q_{e v}\right)$ to the hourly intensity of solar radiation $\left(I_{t}\right)$ as:

$\eta_{i}=q_{e v} / I_{t}$

\section{$>$ Internal efficiency $\left(\boldsymbol{\eta}_{\text {int }}\right)$}

It is the ratio of the heat transferred that utilized for evaporation $\left(q_{e v}\right)$ to the absorbed heat in the basin as:

$\eta_{\text {int }}=\boldsymbol{q}_{\boldsymbol{v}} /\left(\boldsymbol{\alpha}_{w} \boldsymbol{\tau}_{c} \boldsymbol{I}_{t}\right)$

Where: $\alpha_{w}$ is the absorptivity of water and $\tau_{c}$ is the transmissivity of glass cover.

\section{RESULTS AND DISCUSSION}

Obtained results will be discussed under the following heads:

\section{Thermal Figures of Merit}

\subsection{Standard stagnation temperature (SST)}

The effect of different treatments on SST at the maximum solar radiation of $600 \mathrm{~W} / \mathrm{m}^{2}$ was tabulated in Table 2 . 
Obtained results clarified that use of mirror glass reflector coupled with cooker $\left(\mathrm{C}_{2}\right)$ achieved highest temperatures, highest SST and thereby, shortest cooking time comparing with $\mathrm{C}_{1}$ and $\mathrm{C}_{3}$, this is agreement with Kimambo (2007).

The use of system $\mathrm{C}_{4}$ gave the superior results of SST than the other systems. It was $0.161^{\circ} \mathrm{C} . \mathrm{m}^{2} / \mathrm{W}$ due to the effect of solar air cooker and mirror reflector.

Table 2. Standard stagnation temperature

\begin{tabular}{cccc}
\hline Systems & $\begin{array}{c}\text { Ambient } \\
\text { temperature, }{ }^{\mathbf{o}} \mathbf{C}\end{array}$ & $\begin{array}{c}\text { Plate } \\
\text { temperature, }{ }^{\mathbf{o}} \mathbf{C}\end{array}$ & $\begin{array}{c}\mathbf{S S T}, \\
{ }^{\mathbf{0}} \mathbf{C . m}^{2} / \mathbf{W}\end{array}$ \\
\hline $\mathbf{C}_{\mathbf{1}}$ & 32 & 88.0 & 0.093 \\
$\mathbf{C}_{\mathbf{2}}$ & 33 & 105.5 & 0.121 \\
$\mathbf{C}_{\mathbf{3}}$ & 32 & 102.5 & 0.118 \\
$\mathbf{C}_{\mathbf{4}}$ & 31 & 127.5 & 0.161 \\
\hline
\end{tabular}

So, it is recommended to use solar cooker coupled with mirror reflector and solar air collector $\left(\mathrm{C}_{4}\right)$ under all experiments.

\subsection{Cooker temperature}

The following experiments were carried out to select the optimum load that gave a sufficient performance of solar cooker. Fig. 4 showed the effect of different loads of 1.0, 1.5, 2.0 and $2.5 \mathrm{~L}$ of water on cooker temperature using $\mathrm{C}_{4}$ system.

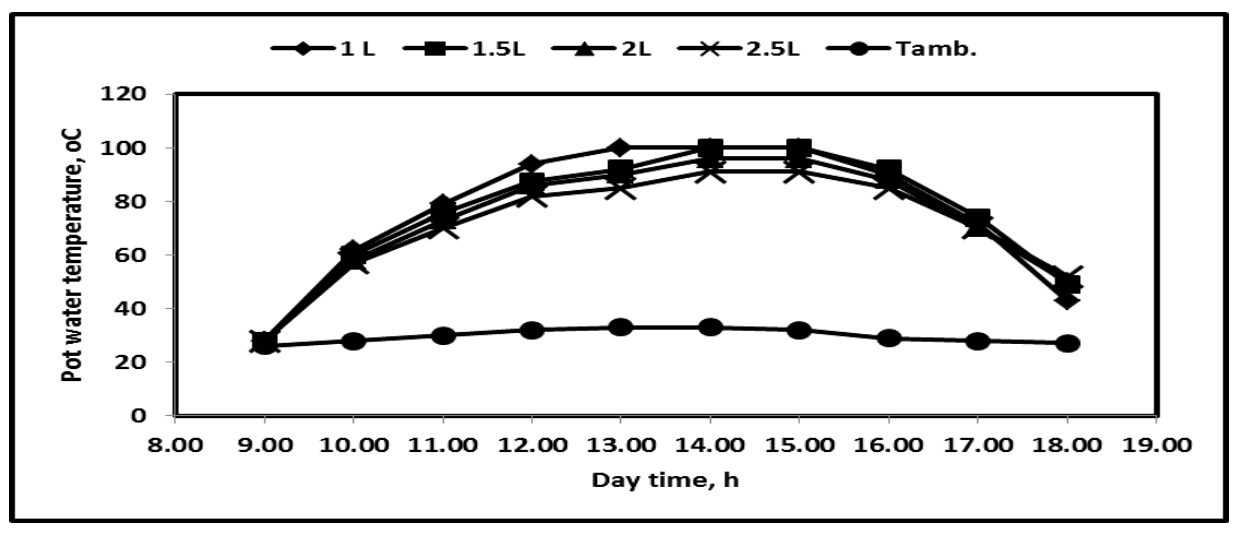

Fig. 4. Effect of water loading on the pot water temperature

It was obvious that the cooker temperature was increased during the hourly day due to solar radiation up to reach their maximum values at $2 \mathrm{pm}$ and then decreased. The peak values of water temperatures were 
$100,100,96,91^{\circ} \mathrm{C}$ for $1.0,1.5,2.0$ and $2.5 \mathrm{~L}$, respectively at ambient temperature of $33^{\circ} \mathrm{C}$ and solar radiation of $600 \mathrm{~W} / \mathrm{m}^{2}$. High load of water needs more time to reach the maximum value of the temperature. These results are in agreement with Kumar (2005).

\subsection{Standard cooking power}

Related to the effect of water load on the cooking power as shown in Fig.5, obtained results indicated that a linear regression relationship between $P_{n}$ and $T_{w}-T_{a m b}$. The linear regression equations and the values of the coefficient of determination $\left(\mathrm{R}^{2}\right)$ of the equations were 0.900 , $0.936,0.887$ and 0.847 for $1.0,1.5,2.0$ and $2.5 \mathrm{~L}$ of water, respectively.
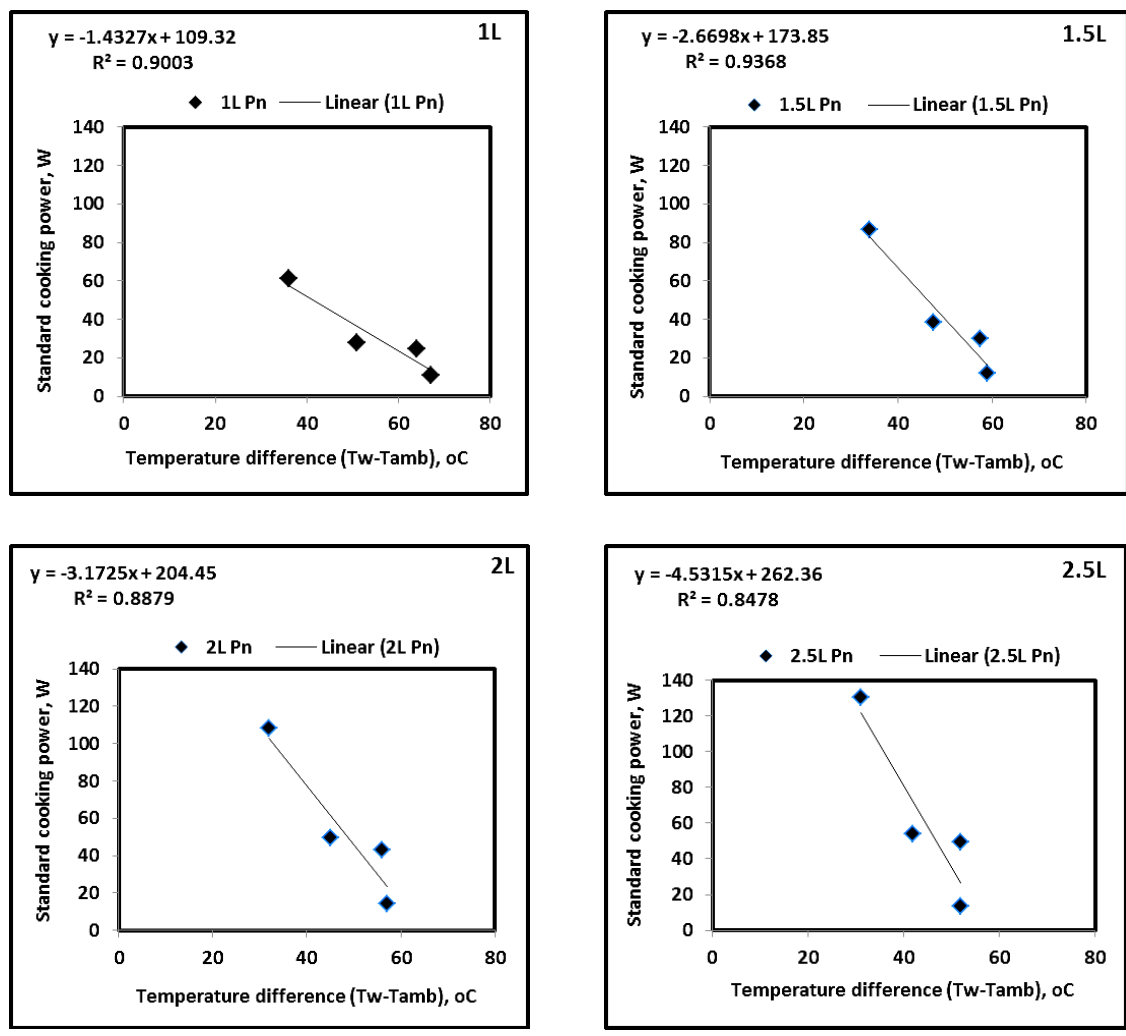

Fig. 5. Relationship between standard cooking power and temperature difference under different water loads

The standardized cooking power was found to be inversely proportional to temperature difference $\left(\mathrm{T}_{\mathrm{w}}-\mathrm{T}_{\mathrm{amb}}\right)$. There was a highly positive relation with high $\left(\mathrm{R}^{2}\right)$. These results are in agreement with Nasr et al. (2007). 


\subsection{Standard sensible heating time and unattended cooking time}

Standard sensible heating time $\left(\mathrm{T}_{0}\right)$ and unattended cooking time $\left(\mathrm{T}_{\mathrm{c}, \mathrm{s}}\right)$ under different pot water loads were illustrated in Table 3.

High loads of water in cooker pot, consumed more time to reach water the temperature of $50^{\circ} \mathrm{C}$ above ambient temperature. The standard sensible heat was $0.96,1.53,1.56$ and $1.68 \mathrm{~h}$ for $1.0,1.5,2.0$ and $2.5 \mathrm{~L}$ of water respectively. These results are compatible with El-Sebaii and Ibrahim (2005).

Table 3. Standard sensible heating time and unattended cooking time under different water loads

\begin{tabular}{ccc}
\hline Water load, $\mathbf{L}$ & $\begin{array}{c}\text { Standard sensible } \\
\text { heating time, } \mathbf{h}\end{array}$ & $\begin{array}{c}\text { Unattended } \\
\text { cooking time, } \mathbf{h}\end{array}$ \\
\hline $\mathbf{1 . 0}$ & 0.96 & 4.32 \\
\hline $\mathbf{1 . 5}$ & 1.53 & 4.39 \\
\hline $\mathbf{2 . 0}$ & 1.56 & 4.45 \\
\hline $\mathbf{2 . 5}$ & 1.68 & 4.52 \\
\hline
\end{tabular}

Respecting to unattended cooking time, different water loads of 1.0, 1.5, 2.0 and $2.5 \mathrm{~L}$ took duration time of about $4.32,4.39,4.45$ and $4.52 \mathrm{~h}$ to decreases by $20^{\circ} \mathrm{C}$ from its maximum temperature.

\section{Cooking Thermal Efficiency $\left(\eta_{u}\right)$}

In relation to the effect of using different water loads on cooking thermal efficiency as shown in Fig. 6.

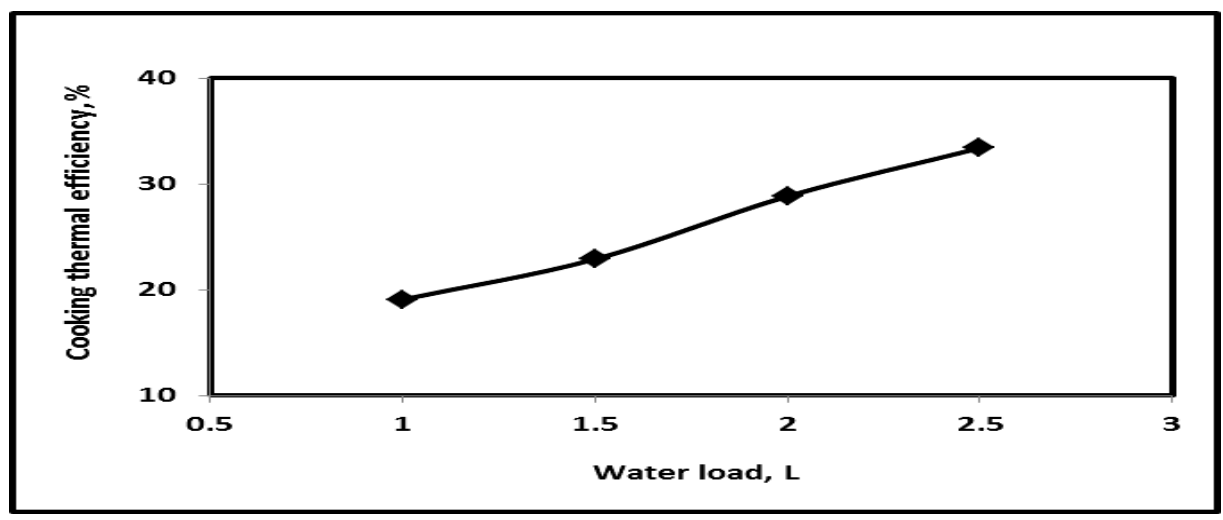

Fig. 6. Cooking thermal efficiency under different water loads

Obtained data explained that cooking efficiency was increased by increasing the quantity of water in the pot according to El-Sebaii and 
Ibrahim (2005). Their values were 19.08, 22.89, 28.83 and $33.39 \%$ for $1.0,1.5,2.0$ and $2.5 \mathrm{~L}$ of water, respectively.

As previous obtained results, it can be concluded that use of the developed solar combination unit which coupled with solar air collector and mirror reflector under water loading of $1.5 \mathrm{~L}$ gave a sufficient efficiency with highest stagnation temperature.

\section{Distillate Water Productivity under Different Parameters}

The effect of solar radiation on the hourly distillate water productivity through a day under different brine depths was illustrated in Fig. 7. It can be noticed that the water productivity was low at the first and thereafter, started to increase with increasing the solar radiation and reached to the peak values at 2 p.m. which equalization the highest solar radiation of 600 $\mathrm{W} / \mathrm{m}^{2}$ and then, decreased under all experimental conditions.

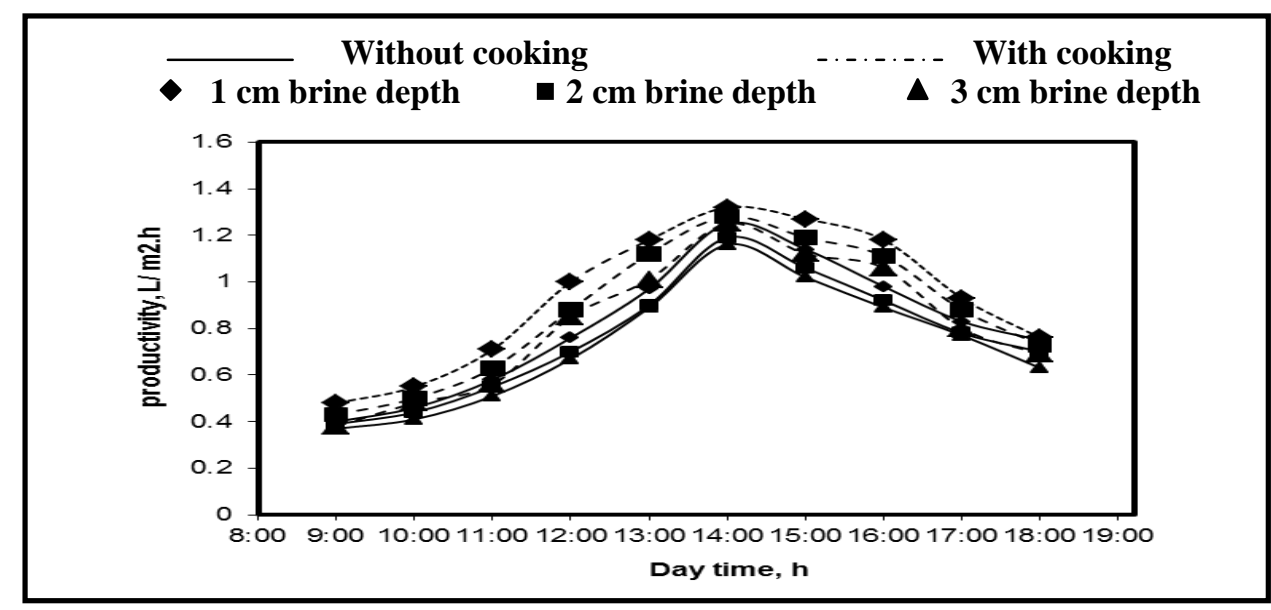

Fig. 7. Effect of solar combination unit treatments on the distillate water productivity under different brine depths

Solar cooker was modified as a still; the capacity has been enhanced by pushing the hot air from the solar air collector in the water basin. Flowing of air over the hot saline water stream gave the best performance than the conventional solar still as mentioned from Elminshawy et al. (2015). Mixing of air and water in the bubble column enhances the heat and mass transfer rate between the hot water and air in that chamber. The air is loaded by humidity leads to higher specific humidity of air and thereby, increasing the distillate water productivity. Obtained results proved that the highest daily productivity using solar air collector coupled with solar 
still reached to $9.38 \mathrm{~L} / \mathrm{m}^{2}$.day at brine depth of $1 \mathrm{~cm}$ under combination of solar desalination and cooking systems. The conventional solar still gave water productivity from 3 to $7 \mathrm{~L} / \mathrm{m}^{2}$.day, which considered low amount and insufficient from the economic point of view as reported by El-Sebaii and Shalaby (2015).

Regarding the effect of brine water depths on productivity, obtained results indicated that the distillate water productivity was decreased by increasing the depth. It reached to the peak values at shallow basin brine depth of $1 \mathrm{~cm}$ as a lowest depth. The productivity was $1.32,1.28,1.25$ $\mathrm{L} / \mathrm{m}^{2}$.h under the conditions of desalination integrated with potato cooking, while it was $1.25,1.19$ and $1.16 \mathrm{~L} / \mathrm{m}^{2}$.h under the conditions of desalination only (without cooking) at 1,2 and $3 \mathrm{~cm}$ brine depths, respectively. Absorbed solar radiation was increased by increasing the brine depths, which decreased thermal system capacity. This is agreed with Abu-Arabi and Zurigat (2005) and Morad et al. (2015).

Concerning the effect of solar combination unit coupled with or without cooking on the distillate water productivity. Data clarified that combined systems of cooking with desalination enhanced the performance and gave better productivity. Daily production was $9.38,8.75$ and $8.20 \mathrm{~L} / \mathrm{m}^{2}$.day with the use of the solar combination unit, while $8.12,7.63$ and 7.32 $\mathrm{L} / \mathrm{m}^{2}$.day under the use of desalination system only for 1,2 and $3 \mathrm{~cm}$ brine depths. This is due to high internal convective, evaporative and radiative heat transfer from water to glass cover with the solar combination unit (combination systems of cooking and desalination at the same time), which reflected on increasing the water productivity.

\section{Internal and Instantaneous Thermal Efficiencies}

Internal and instantaneous thermal efficiencies were determined at maximum solar radiation under different parameters as shown in Fig. 8.

Results showed that increasing the brine depths, instantaneous and internal thermal efficiencies were decreased. This decrease attributed to higher thermal storage accompanied with increasing water brine mass. By the use of solar combination unit for desalination with cooking treatment, internal and instantaneous efficiencies were decreased from 60.17 to $46.26 \%$ and 41.43 to $31.85 \%$ by increasing the brine water depths from 1 to $3 \mathrm{~cm}$. However using the desalination treatment without cooking, 
thermal efficiencies were decreased from 55.41 to $43.27 \%$ and from 38.15 to $30.10 \%$, in that order.

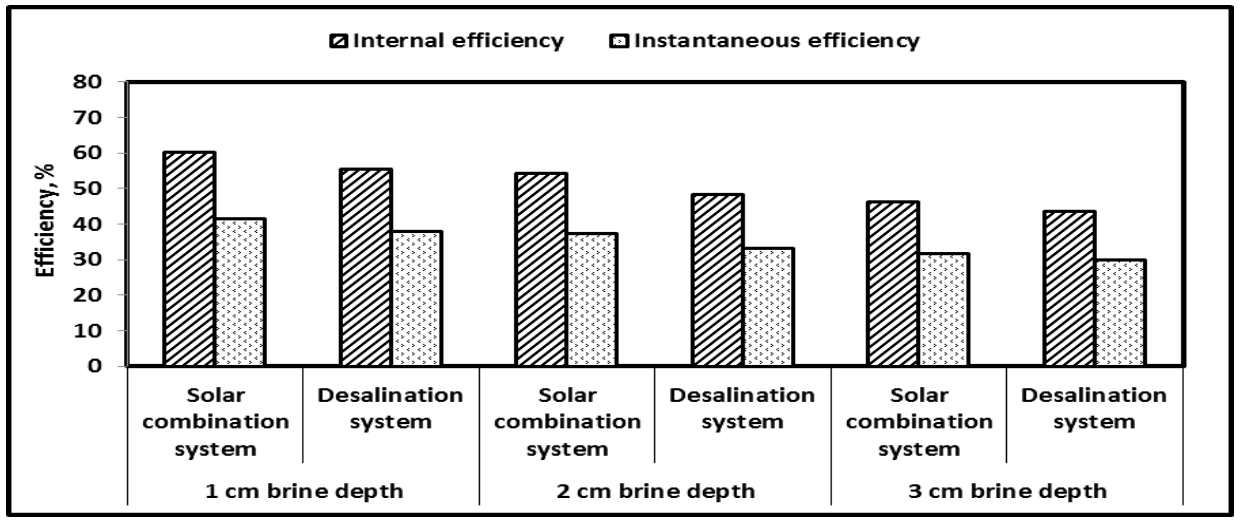

Fig. 8. Effect of solar combination unit on internal and instantaneous thermal efficiencies under different brine depths

Comparing the efficiencies between the two used modes, data revealed that thermal efficiencies were greater by the use of the desalinationcooking mode than that for the desalination mode only. Using solar cooking coupled to the desalination process added thermal energy through the day hours. High difference in temperature by the use of desalinationcooking combined systems increased the distillate water outlet, resulting in high system efficiencies.

Based on above mentioned results, it was concluded that brine depth of $1 \mathrm{~cm}$ and the solar combination unit gave the highest productivity and thermal efficiencies compared to other treatments.

\section{Cooking Time}

Cooking time is an important parameter that determines the effectiveness of the cooker. Effect of using two modes (cooking without desalination process and desalination-cooking combined systems at $1 \mathrm{~cm}$ brine depth) on the duration cooking time of rice $\left(\mathrm{T}_{1}\right)$, potato $\left(\mathrm{T}_{2}\right)$, cake $\left(\mathrm{T}_{3}\right)$, egg+ potato+ rice $\left(\mathrm{T}_{4}\right)$ was presented in Fig. 9

It was observed that the duration time for cooking products $T_{1}, T_{2}, T_{3}$ and $\mathrm{T}_{4}$ was 45, 50, 60 and 120 min using the system as a solar cooker, while 39, 43, 49 and 100 min by the use of solar combination unit, respectively. This is due to the effect of combination system, resulting in high thermal 
energy and therefore, decreases in cooking time comparing with another system.

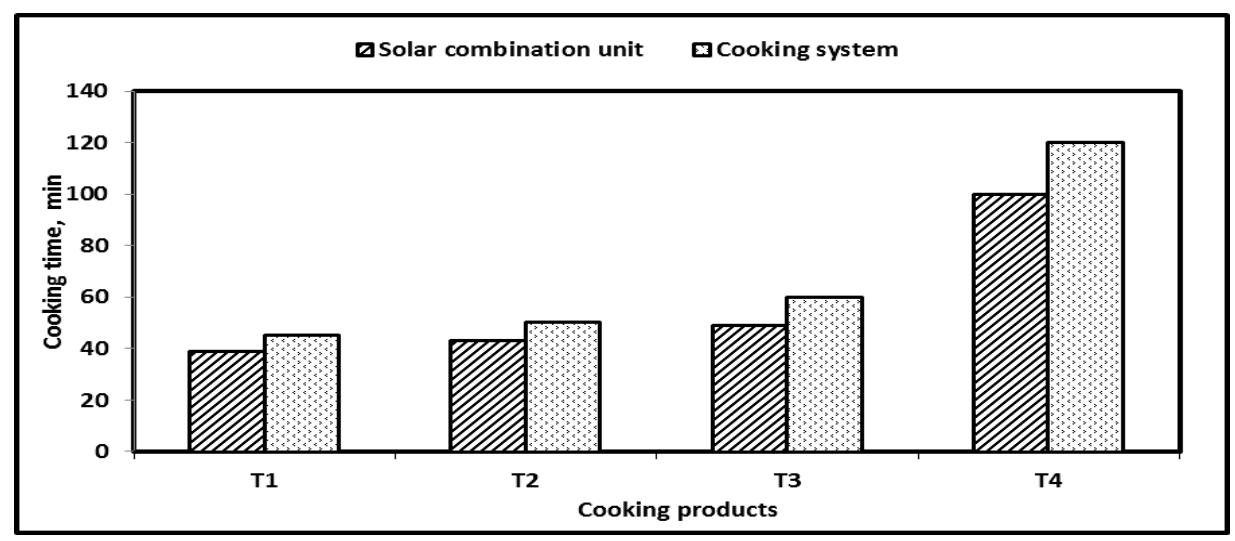

Fig. 9. Effect of solar combination unit on the cooking time CONCLUSIONS

The experimental results reveal to the following:

1. Solar cooker integrated with flat plate solar collector and mirror reflector gave the highest $\mathrm{SST}\left(0.161{ }^{\circ} \mathrm{C} \cdot \mathrm{m}^{2} / \mathrm{W}\right)$ compared to other systems under study.

2. By increasing water loads, the standard cooking power, thermal efficiency, standard sensible heating time and unattended cooking time were increased.

3. Maximum distillate water productivity was $9.38 \mathrm{~L} / \mathrm{m}^{2}$.day for solar combination unit, while $8.12 \mathrm{~L} / \mathrm{m}^{2}$.day under desalination system correlated to maximum ambient temperature and solar radiation.

4. The highest obtained internal and instantaneous efficiencies were $60.17 \%$ and $41.43 \%$, respectively under the use of solar combination unit with $1 \mathrm{~cm}$ brine depth.

5. Cooking time was (39 and $45 \mathrm{~min}$ ) for rice, (43 and $50 \mathrm{~min}$ ) for potato, (49 and $60 \mathrm{~min}$ ) for cake and (100 and $120 \mathrm{~min}$ ) for egg + potato + rice by the use of desalination-cooking combined systems and cooking treatment only, in that order.

So, it can be concluded that using the developed solar combination unit gave sufficient results for desalination and cooking at the same time under conditions of pot water loading of $1.5 \mathrm{~L}$ and brine depth of $1 \mathrm{~cm}$. 


\section{REFERENCES}

Abu-Arabi, M. and Y. Zurigat (2005). Year round comparative study of three types of solar desalination units. Desalination, 172: 137-143.

Al-Enezi, G; H. Ettouney and N. Fawzy (2006). Low temperature humidification dehumidification desalination process. Energy Conversion and Management, 47: 470 - 484.

ASAE Standards S580 (2003). Testing and reporting solar cooker performance. Structures and Environment Division Standards Committee.

Bhalme, N. S. and P. R. Pachghare (2017). Performance analysis of solar desalination system using humidification and dehumidification cycle. International Journal of Innovative Research in Science, Engineering and Technology, 6(6): 10635 - 10643.

El-Sebaii, A. A. and A. Ibrahim (2005). Experimental testing of a boxtype solar cooker using the standard procedure of cooking power. Renewable Energy, 30(12):1861-1871.

El-Sebaii A. A. and S. M. Shalaby (2015). Parametric study and heat transfer mechanisms of single basin V-corrugated solar still. desalination and water treatment, 55: $285-296$.

Elminshawy, N. A. S; F. R. Siddiqui and M. F. Addas (2015). Experimental and analytical study on productivity augmentation of a novel solar humidification-dehumidification (HDH) system. Desalination, 365: 36 - 45 .

Hafner, B. C. and F. C. Schwarzer (2000). Methods for the design and thermal characterization of solar cooker. Solar Institute Juelich, Fachhochschule Aachen, Germany.

Kabeel E. A; M. H. Hamed, Z. M. Omara and S. W. Sharshir (2013). Water desalination using a humidification-dehumidification technique a detailed review. Natural Resources, 4: 286 - 305. 
Kimambo, C. Z. M. (2007). Development and performance testing of solar cookers. Department of Energy, University of Dar es Salaam. J. of Energy in Southern Africa, 18(3).

Kumar, S. (2005). Estimation of design parameters for thermal performance evaluation of box type solar cooker. Renewable Energy, 30(7):1117 - 1126.

Morad, M. M; H. A.M. El-Maghawry and K. I. Wasfy (2015). Improving the double slope solar still performance by using flatplate solar collector and cooling glass cover. Desalination, 373: 1-9.

Mona M. A. Hassan (2012). Development and evaluate a solar cooker to be used for cooking and drying some agricultural products. $19^{\text {th }}$ Annual Conference of the Misr Soc. of Ag. Eng., 193 - 212.

Moumouh, J; M. Tahiri, M. Salouhi and L. Balli (2016). Theoretical and experimental study of a solar desalination unit based on humidification-dehumidification of air. International journal of hydrogen energy, $1-5$.

Nasr, M; M. Hassan, A. M. Kishta and Y. A. Habib (2007). Designing and testing a solar cooker for remote areas. M.Sc., Faculty of Agriculture, Zagazig University.

Sampathkumar, K; T. V. Truman, P. Pitchandi, P. Senthilkumar (2010). Active solar distillation-A detailed review. Renewable and Sustainable Energy Reviews, 14 (6): 1503 - 1526.

Srithar, K. and T. Rajaseenivasan (2017). Performance analysis on a solar bubble column humidification dehumidification desalination system. Process safety and environmental protection, 105: 41-50.

Tiwari, G. N; S. K. Shukla and I. P. Singh (2003). Computer modelling of passive and active solar stills by using inner glass temperature. Desalination, 154: 171 - 185 .

Yuan, G; Z. Wang, H. Li and X. Li (2011). Experimental study of a solar desalination system based on humidification dehumidification process. Desalination, 277: 92 - 98 . 


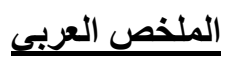 \\ وحدة شمسية مطورة مجمعة للطبخ وتحلية المياه

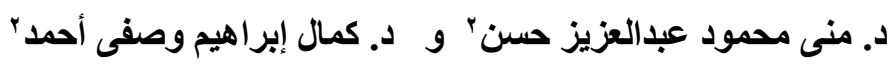

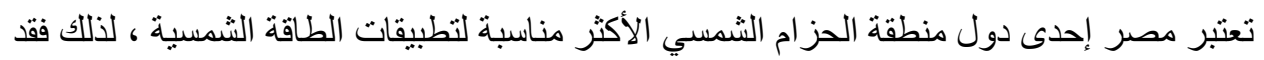

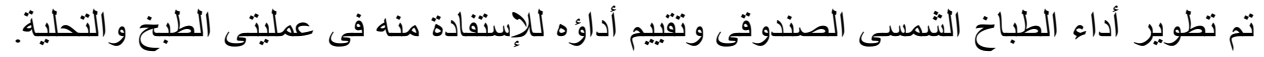

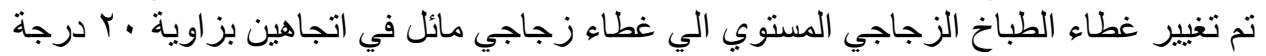

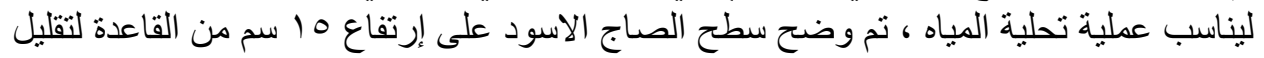

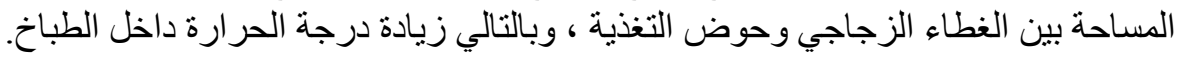

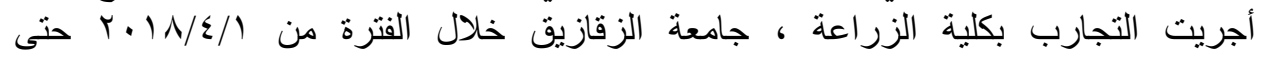

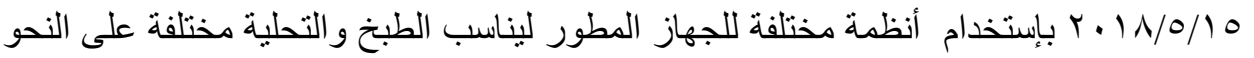

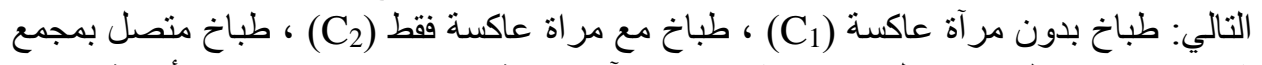

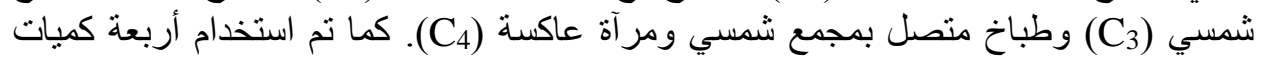

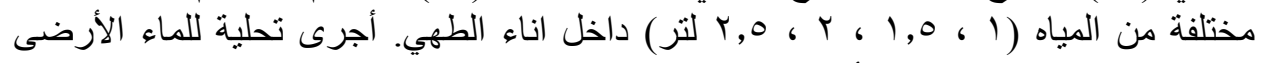

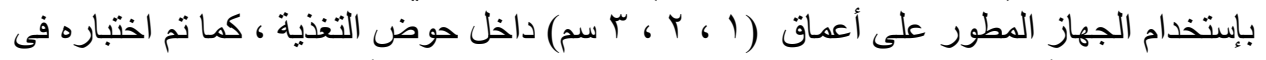

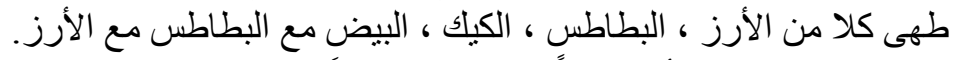

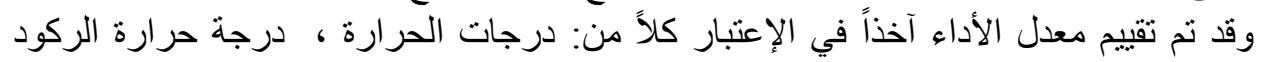

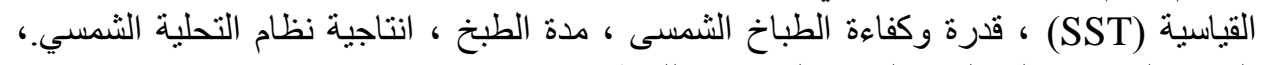

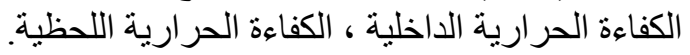

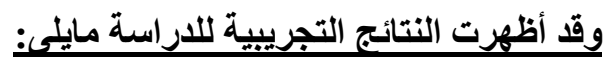

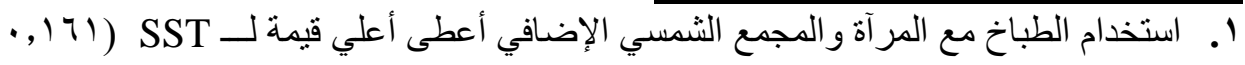

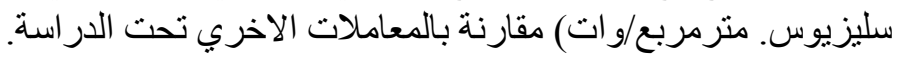

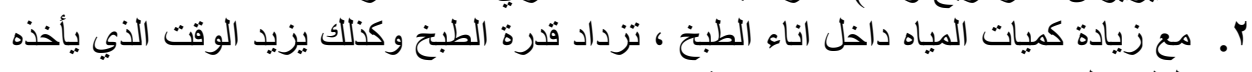

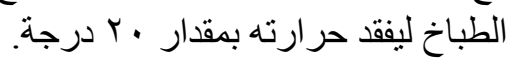

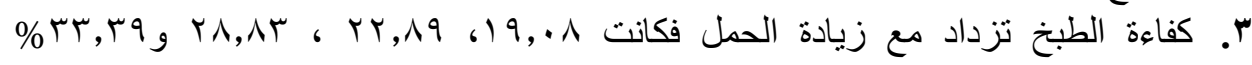

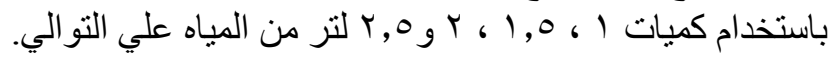

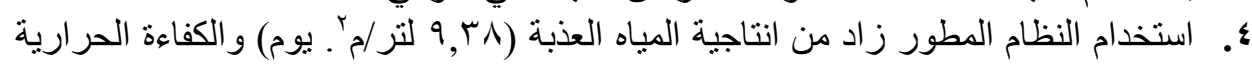

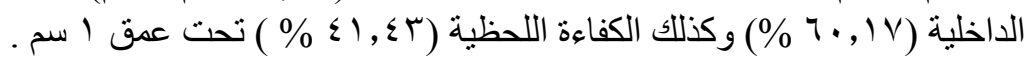

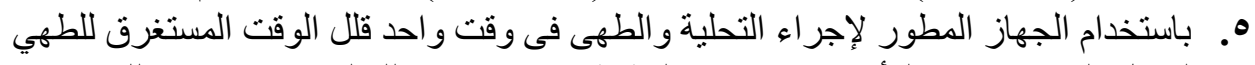

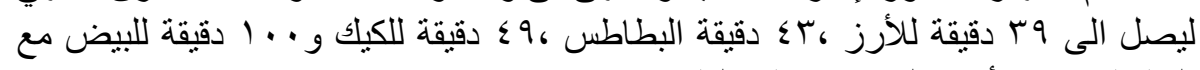

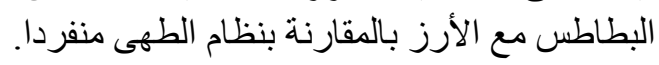

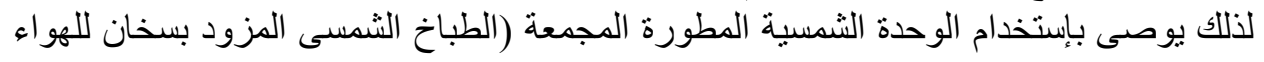

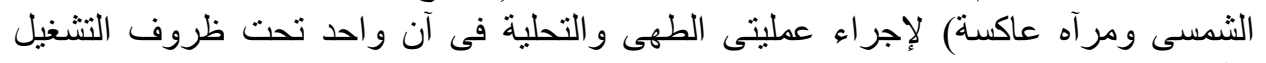

• عمق التة: سم من المياه المالحة داخل الحوض.

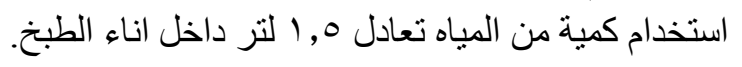

r أستاذ الهندسة الزراعية المساعد ـ كلية الزراعة - جامعة الزقازيق. 